Portland State University

PDXScholar

$1-1-2012$

\title{
Lay Versus Medical Analysis: A Conflict Centered on the Disciplinary and Professional Identity of Psychoanalysis
}

Sam Yoder

Portland State University

Follow this and additional works at: https://pdxscholar.library.pdx.edu/honorstheses

Part of the History Commons

Let us know how access to this document benefits you.

Recommended Citation

Yoder, Sam, "Lay Versus Medical Analysis: A Conflict Centered on the Disciplinary and Professional Identity of Psychoanalysis" (2012). University Honors Theses. Paper 11.

https://doi.org/10.15760/honors.11

This Thesis is brought to you for free and open access. It has been accepted for inclusion in University Honors Theses by an authorized administrator of PDXScholar. Please contact us if we can make this document more accessible: pdxscholar@pdx.edu. 


\title{
LAY VERSUS MEDICAL ANALYSIS: A CONFLICT CENTERED ON THE DISCIPLINARY AND PROFESSIONAL IDENITY OF PSYCHOANALYSIS
}

\author{
by \\ Sam Yoder \\ A thesis submitted in partial fulfillment of the requirements for the \\ degree of

\section{BACHELOR OF ARTS WITH HONORS} \\ in \\ HISTORY
}

Portland State University 2012 


\section{Table of Contents}

Chapter I: Introduction and Historiography. 1

Chapter II: Events Leading Up to the Conflict over Lay Analysis. 10

Chapter III: Arguments for Allowing the Practice of Lay Analysis. 19

Chapter IV: Arguments for the Integration of Psychoanalysis with Medicine as well as the Ban of Lay Analytic Practice. 31

Chapter V: The Psychoanalytic Civil Wars, a Continuation of the Conflict. 46

$\begin{array}{lc}\text { Bibliography } & 58\end{array}$ 


\section{Chapter I: Introduction and Historiography}

In 1985, a group of four psychologists, on the behalf of a declared class of several thousand psychologists, filed a class action lawsuit against the American Psychoanalytic Assocation with the charge of promoting a conspiracy to disallow non-physicians from gaining access to psychoanalytic training. These psychologists claimed that the APsaA was in direct violation of the Sherman Anti-Trust Act. Eventually, the lawsuit was settled in 1988 in the favor of the psychologists. ${ }^{1}$ This lawsuit was the resolution of a conflict that had plagued psychoanalysis for about sixty-five years. Starting in the 1920's, psychoanalysis was split by disagreements between lay and medical analysts. The conflict centered around whether psychoanalysts needed to have a medical degree to practice psychoanalysis, or if psychoanalysis was its own discipline and should not reside under medical regulation. In this paper, I explore and analyze the different arguments that were made in the conflict between lay and medical analysis. Using both primary and secondary source material on this topic, I show how this psychoanalytic conflict is an expression of two conflicting ideas for the disciplinary identity of psychoanalysis. The first idea was that psychoanalysis should be a bridging discipline that would connect multiple disciplines together. This was the opinion held by the lay analysts, many of whom came from a variety of disciplinary backgrounds. Medical analysts presented an opposing view in which they believed psychoanalysis needed to be tied to medical disciplines,

\footnotetext{
${ }^{1}$ Robert Wallerstein, Lay Analysis: Life Inside the Controversy (Hillsdale: The Analytic Press, 1998), 309
} 
namely psychiatry. They believed that psychoanalysis would gain legitimacy if it was tied to the medical field. Furthermore, the examination of this conflict allows readers to understand the concepts of professionalization, which arises within discipline formation. In particular, this discussion of professionalization centers upon the training and educational requirements for becoming a professional within psychoanalysis. This exploration of the historic psychoanalytic conflict is presented in five chapters. The first chapter is an analysis of the historiography for the history of psychiatry and psychoanalysis. In this first chapter, I discuss how psychoanalytic history has been integrated into the history of psychiatry versus a stand-alone presentation of psychoanalytic history. Both of these methods produce problems provide comparison to the arguments made by lay and medical analysts. The second chapter details the events that led up to the main conflict in 1927 which includes the Flexner Report, a survey of American medical schools sponsored by the Carnegie Foundation, and its role in the professionalization of medical schools in the United States, as well as an exposition of why Sigmund Freud became opposed to the idea of medicine being involved with psychoanalysis. The third and fourth chapters analyze the different arguments that were made on behalf of lay and medical analysis. It includes events such as the 1927 International Psychoanalytic Association Symposium on Lay Analysis and the American ultimatum against lay analysis known as the 1938 Rule. It also examines the writings of several prominent psychoanalysts and their arguments on the subject. The final chapter analyzes the paradoxical events that took place following the 1938 rule. These events show an inability to unify the psychoanalytic community and how a power struggle occurred between analysts to become successor to Freud. Additionally, this section enlightens readers as to how lay analysis continued through the help of lay analyst Theodore Reik and his underground movement the National Psychological Association for Psychoanalysis. 
Historians have studied psychoanalysis and psychiatry through many lenses including discussions of gender, political science, sociology, and anthropology. In relation to my argument, I want to examine the relationship between historical presentations of psychoanalysis as a part of the history of psychiatry versus a standalone arrangement of psychoanalysis as its own historical narrative. Both of these views provide a unique historical perspective for studying these topics. What is even more germane to my argument is that after careful examination of these historians, one can see how many aspects of the conflict between lay and medical analysts have also arisen within historical discourse.

Psychoanalysis is frequently presented in two different historical methods. The first method considers psychoanalysis to be a part of the history of psychiatry. An example of this would be Elizabeth Lunbeck's book The Psychiatric Persuasion: Knowledge, Gender, and Power in Modern America. In this book, Lunbeck is largely interested in understanding the gender and power dynamics within American psychiatry during the early twentieth century. Additionally, she often mentions psychoanalytic concepts and practitioners throughout her text when discussing ailments such as hysteria and hypersexuality. ${ }^{2}$ Historians that practice this method categorize psychoanalysis as a subsidiary part of psychiatry. There are interesting implications that arise when carefully considering this historical categorizing. First of all, this categorization presents a counter argument to the disciplinary autonomy that many psychoanalytic practitioners strove for in the early and mid twentieth century. This approach in effect takes for granted the historical outcome of the conflict over lay analysis rather than interrogating its origins. In this sense, American analysts, most of who believed that psychoanalysis should be tied to medical psychiatry, assumed that psychoanalysis was an

\footnotetext{
${ }^{2}$ Elizabeth Lunbeck, The Psychiatric Persuasion: Knowledge, Gender, and Power in Modern America (Princeton: Princeton University Press, 1994), 210.
} 
important technique for psychiatrists in the treatment of mentally ill patients. On the other hand, Freud's stance, shared by many of his European colleagues, was that psychoanalysis was its own unique discipline that did not fall under the control of medicine. When comparing the differing methods for the historiography of psychoanalysis, juxtaposed with how lay and medical analysts argued over the disciplinary identity of psychoanalysis, one can see the similar themes that arise within both psychoanalytic and historiographical discussions.

The other frequently used method for historical examinations of psychoanalysis centers upon the idea of psychoanalysis as its own distinct discpline. This method includes historical works like Edith Kurzweil's The Freudians or Nathan G. Hale's two part series on the history of American psychoanalysis. Kurzweil's book in particular, provides an excellent example for this method when she examines the relationship between trends in both psychoanalysis and how different countries shaped those trends. ${ }^{3}$ Historical texts like Kurzweil's and Hale's focus less upon actual techniques, treatment methods, and case studies and more on events surrounding psychoanalysis and its relationship to a particular country or society.

Additionally, Freud relationship to psychoanalysis complicates the historiography of psychoanalysis. When a discipline has a polarizing figurehead, there is obviously going to be a lot of historical work done on how that person fit into that discipline. Sigmund Freud is arguably one of most renowned figureheads that any discipline has ever had. Freud created the psychoanalytic treatment method and founded the International Psychoanalytic Assocation. Not only is he a figurehead for psychoanalysis but he is a figure synonymous with psychotherapy and mental health science in general. In this case, historians have been fascinated with Freud and his relationship with psychoanalysis. This fascination has led some historians to question whether

\footnotetext{
${ }^{3}$ Edith Kurzweil, The Freudians (New Haven: Yale University Press, 1989), 1.
} 
psychoanalysis is a credible subject for historical study. Historians that are critical of this fascination with Freud categorize psychoanalytic material as psychobiographies of Freud. Elisabeth Young-Bruehl in her article "A History of Freud Biographies" makes the claim that historical psychoanalytic accounts are not really historical because they center primarily on Freud. Consequently, psychoanalysis does not have a history apart from the biography of Freud. ${ }^{4}$ This argument is surely debatable and countered by historiographical texts such as Hale's volumes on the history of American psychoanalysis, which detail the history of psychoanalysis as being more distinct than just a part of the history of psychiatry.

In addition to the ways in which psychoanalysis has been categorized in historical analyses, it is equally important to understand the people that are writing this history. The history of psychiatry and psychoanalysis is oftentimes written by former practitioners of these two disciplines. Both historians Roy Porter and Mark Micale noticed that psychiatrists construct both the history and historiography of their discipline and that these writings are sometimes considered to be a self-representation of a psychiatrist's medical and professional status. ${ }^{5}$ Their work brings about special considerations that readers of psychiatric and psychoanalytic history must be aware of. Historian and psychoanalyst Kurt Eissler wrote an extensive account on the conflict surrounding lay and medical analysis. ${ }^{6}$ However, it is important to realize that Eissler was a practicing psychoanalyst during the time period of this conflict and his views were heavily aligned with Freud's on the side of lay analysts; therefore, Eissler has an agenda and a particular

\footnotetext{
${ }^{4}$ Elisebeth Young-Bruehl, "A History of Freud Biographies," in Discovering the History of Psychiatry (New York: Oxford University Press, 1994), 158.

${ }^{5}$ Mark S. Micale and Roy Porter, "Reflections on Psychiatry and its Histories," in Discovering the History of Psychiatry (New York: Oxford University Press, 1994), 13.

${ }^{6}$ Kurt Eissler, Medical Orthodoxy and the Future of Psychoanalysis (New York: International Universities Press, 1965).
} 
investment upon this certain issue. In the end, this can be problematic for someone who wants to use this historical material for an unbiased presentation of these events. With this paper, I do not make an argument about whether lay or medical analysis is correct. Nevertheless, it can be difficult to construct an argument when historians have agendas or bias on the material they are presenting.

It is obvious that these historians of psychiatry and psychoanalysis have passionate and personal investment in their historical accounts. This passion is compounded by the fact that the material they are discussing can be controversial within their respective communities. Freud wrote On the History of the Psychoanalytic Movement a book in which he wrote about how psychoanalysis had developed. ${ }^{7}$ John Forrester wrote in his article "A Whole Climate of Opinion: Rewriting the History of Psychoanalysis" that in On the History of the Psychoanalytic Movement Freud is implying that the history of psychoanalysis is built upon these resistances and attacks but of course this is a generalization of psychoanalytic history. ${ }^{8}$ Both Freud and Eissler are examples of practicing psychoanalysts who are writing their own history with a particular agenda.

The following account of the interaction between Albert Duetsch and Gregory Zillboorg provides further insight into how the conflict of lay and medical analysis is mirrored in the historical analyses. Deutsch, an early American historian of psychiatry, wrote The Mentally Ill in America which is widely considered by historians to be a landmark text for the historiography

${ }^{7}$ Sigmund Freud, On the History of the Psychoanalytic Movement (New York: W.W. Norton \& Company, 1914).

${ }^{8}$ John Forrester, "A Whole Climate of Opinion: Rewriting the History of Psychoanalysis," in Discovering the History of Psychiatry (New York: Oxford University Press, 1994), 175. 
of psychiatry. ${ }^{9}$ It is a historical survey of the treatment and care of mentally ill patients in America. Until this book, no one had written a historical text on the American history of psychiatry. Following shortly after Deutsch's publication of The Mentally Ill in America, Gregory Zillboorg, a prominent member of the New York Psychoanalytic Society, wrote $A$ History of Medical Psychology in 1941. Zillboorg's text focused primarily on the European history of psychiatry and included very little on American psychiatry. In response to questions on why he left out material on American psychiatry, Zillboorg stated that the subject required its own special focus. ${ }^{10}$ Zillboorg would have surely been aware of the book Deutsch had written just four years prior. However, Zillboorg believed that Deutsch did not have the credibility to write authoritatively on the subject of American Psychiatry because he was not a physician. ${ }^{11}$ Zillboorg's stance against Deutsch is parallel to the argument between lay and medical analysis. Zillboorg believed that Deutsch did not have the proper training to understand psychiatry and therefore he was not qualified to undertake writing its history. Likewise, American psychoanalysts who campaigned against lay analysis felt that without proper medical training, a lay analyst could not adequately perform psychoanalysis. Historians of science do not always practice the sciences that they write about. Therefore, it is curious that Zillboorg would have such a harsh opposition to historians writing about psychiatry without being medically trained. I argue that this sentiment is a product of the disciplinary insecurity that psychiatrists and psychoanalysts had in the mid twentieth century. Critics of psychiatry and psychoanalysis

${ }^{9}$ George Mora, "Early American Historians of Psychiatry," in Discovering the History Psychiatry, (New York: Oxford University Press, 1994), 56-57.

${ }^{10}$ Mora, "Early American Historians of Psychiatry," 61.

${ }^{11}$ Mora, "Early American Historians of Psychiatry," 61-62. 
have questioned the scientific validity of psychoanalysis. In this case, there is arguably no greater critic of those disciplines than Thomas Szasz.

Thomas Szasz began his career with the intent to study psychiatry. However, Szasz could not accept the medical aspirations of psychiatry. Midway through his training, Szasz was instructed by his department chair at the University of Chicago to perform his residency at a mental hospital. Szasz promptly refused, stating that he did not believe that psychiatry had any business being practiced in a hospital. ${ }^{12}$ From that point onward, Szasz became one of the most outspoken critics of psychiatry. He believed that psychiatry was a pseudoscience in the sense that it was based on rhetorical discussions while masquerading as a medical science. ${ }^{13}$ Psychotherapy was a rhetorical exercise that had no medical or scientific basis. Szasz was also critical of the psychiatrists creating and writing their own history. He viewed this as an attempt by psychiatrists to gain power by making their work appear to be based on scientific analysis. ${ }^{14}$ Szasz and work of other critics of psychiatry and psychoanalysis helped start what would later be known as the Anti-Psychiatry movement. The goal of this group was to expose the flaws in psychiatry as a medical science.

The historiography of psychoanalysis and psychiatry seems to be just as chaotic as the events taking place within the disciplines themselves. There are many parallels that one can make between the historians and the practitioners. Perhaps this is best explained by the fact that many psychiatrists and psychoanalysts were engaged in writing the history of their own

\footnotetext{
${ }^{12}$ Lee S. Weinberg and Richard E. Vatz, "The Rhetorical Paradigm in Psychiatry History: Thomas Szasz and the Myth of Mental Illness," in Discovering the History of Psychiatry, (New York: Oxford University Press, 1994) 311.

${ }^{13}$ Weinberg and Vatz, "The Rhetorical Paradigm." 313.

${ }^{14}$ Weinberg and Vatz, "The Rhetorical Paradigm," 314.
} 
discipline. Therefore, it is important to understand these facets of the psychiatric and psychoanalytic historical communities. The questions surrounding disciplinary identity and professional training for historians of psychiatry and psychoanalysis are questions that are shared by the analysts who took part in the conflict between lay and medical analysis. In my subsequent chapters, I explain how these questions manifested themselves within this psychoanalytic conflict; beginning with establishing the events that instigated the debate over lay and medical analysis. 


\section{Chapter II: Events Leading to the Conflict over Lay Analysis}

The conflict surrounding lay analysis was not something that happened overnight. It resulted from a gradual buildup of events that took almost two decades before it became a controversial topic for psychoanalysis. Robert Wallerstein identifies in his book, Lay Analysis: Life Inside the Controversy, that there were two events that initiated this conflict. The first was Freud's publication of the paper “"Wild' Psychoanalysis" in 1910, in which he expressed displeasure with physicians who were claiming expertise in the field of psychoanalysis and misusing psychoanalysis for their own gains. In response to the threat of improper psychoanalytic usage, Freud established the IPA with the purpose of regulating the training and practice of psychoanalysis. ${ }^{1}$ The other event Wallerstein points to is the publication of the Flexner Report in 1910, which presented claims indicating that American medical schools were in dire need of professionalizing reforms. Following the Flexner Report, the American Medical Association initiated a wave of reforms intended to professionalize and legitimize medicine in the United States. ${ }^{2}$ What is important to note about these events is the two opposing paths that they represent. On one hand, there are events including the Flexner Report, that created a desire for professionalization and influenced the American stance against lay analysis. On the other

${ }^{1}$ Robert Wallerstein, The Question of Lay Analysis (Hillsdale: The Analytic Press, 1998), 5.

${ }^{2}$ Wallerstein, The Question of Lay Analysis, 5. 
hand, there was another set of events that led to the creation of the supportive stance for lay analysis held by Freud and other lay analysts.

\section{The Flexner Report.}

In 1910, the Carnegie Foundation for the Advancement of Teaching organized and funded The Flexner Report: on Medical Education in the United States and Canada 1910 with the intent to examine the current state of American medical schools compared to universities in Europe. The Flexner Report was consistent with the Foundation's mission, since its creation in 1905 as one of Andrew Carnegie's many philanthropies, to improve teaching and learning throughout the United States. ${ }^{3}$ The Carnegie Foundation chose Abraham Flexner to conduct a survey of medical schools in the United States. Flexner was surprised that he was chosen to lead this investigation as he thought his brother Simon, a director at the Rockefeller Institute for Medical Research, was more suited for the job. ${ }^{4}$ Before undertaking the survey for his report, Flexner already had a preconception that universities should foster an experiential method for teaching. ${ }^{5}$ His belief that universities were the key for professionalizing medicine was an integral part of the Flexner Report. He began the report with an overview of the history of medical schools in America, in which he detailed how medical schools had developed and changed since around 1750. In the beginning, medical education had taken the form of informal

\footnotetext{
3 “About Carnegie" accessed on May $3^{\text {rd }}, 2012$.http://www.carnegiefoundation.org/aboutus/about-carnegie.

${ }^{4}$ Kenneth M. Ludmerer, "Commentary: Understanding the Flexner Report," Academic Medicine 85 (2010): 193-196.

${ }^{5}$ Ludmerer, "Commentary: Understanding the Flexner Report." 193-196.
} 
classes and demonstrations. ${ }^{6}$ This practice later developed into the first formal medical education which took place in hospitals. Starting in the early 1800 s, however, the scholarly ideals of new physicians became compromised and forgotten. ${ }^{7}$ For the next hundred years, medical education in the United States ignored new developments in scientific knowledge that were vital for diagnosing and treating illnesses. ${ }^{8}$ After exploring the history of medical education in America, Flexner dove into the state of contemporary American medicine. Flexner claimed that there was an overpopulation of doctors in the United States, an assertion he verified through a comparison of the ratios of doctors to patients in Germany and America. In Germany, there was one doctor for every two thousand people. In America, there was one doctor for five hundred sixty-eight people. Flexner concluded that the German ratio of one qualified doctor for two thousand patients was just as efficient at treating patients as one poorly trained American doctor treating fewer patients. ${ }^{9}$ Based on his survey, Flexner argued the purpose for most medical schools in America was to produce as many doctors as possible while also making the most money. Anyone who could pay the basic fee was allowed to enter the program and those students that paid their tuition were almost assured a degree. ${ }^{10}$ Medical schools had varying lengths of programs but the average length was two to three years. ${ }^{11}$ Flexner placed every

\footnotetext{
${ }^{6}$ Abraham Flexner, The Flexner Report: on Medical Education in the United States and Canada 1910 (Washington D.C.: The Carnegie Foundation for the Advancement of Teaching, 1910), 4-6.

${ }^{7}$ Flexner, Medical Education, 5.

${ }^{8}$ Flexner, Medical Education, 9.

${ }^{9}$ Flexner, Medical Education, 14.

${ }^{10}$ Flexner, Medical Education, 6-7.

${ }^{11}$ Flexner, Medical Education, 12.
} 
medical school he visited into one of three possible categories. The first category held schools that had a two or more year curriculum and were comparable to Johns Hopkins University, which Flexner considered to be one of the only credible medical schools in America at that time. The second category included schools that allowed admission for students with a four year high school education or equivalent. The third group consisted of schools that allowed students with little to no common education. ${ }^{12}$ Around one third of all the medical schools Flexner visited fell into the third category. ${ }^{13}$

Flexner believed in scientific medicine, in other words that medical students needed to have an empirical and active understanding of the human body. Active in the sense that students must learn medical procedures by doing them, not just by watching or listening to them. Students also needed awareness of probability and theories pertaining to their field. Flexner surmised that the laboratory was the best place to satisfy the requirements for medical students. Chemistry, physics, and biology were vital to the education of future doctors. Those subjects tied in closely with Flexner's ideas of what constituted scientific medicine. ${ }^{14}$

The publication of the Flexner Report and the consequent reformation of medical schools were landmark events for the history of science and medicine. The report also had a profound effect on the professionalization of other disciplines. Sociologist Michael Schudson, in his study of the effects of the report on professional education in America, points to how the Flexner Report influenced other reform attempts such as the professionalization of lawyers through the

${ }^{12}$ Flexner, Medical Education, 29.

13 Thomas P. Duffy, “The Flexner Report: 100 Years Later," Yale Journal of Biology and Medicine 77 (2011): 272.

${ }^{14}$ Flexner, Medical Education, 53. 
Reed Report. ${ }^{15}$ In discussing the Flexner Report itself, he argues that the overpopulation of American physicians would have eventually reduced itself over time, but the Flexner report rapidly advanced this process. In fact, by 1920, the number of medical schools in the United States declined by an astounding seventy-nine schools out of one hundred fifty-five. ${ }^{16}$

Flexner conceptualized new professionalized occupations, not only for medicine but also for other disciplines. In a 1915 lecture to the National Conference for Charities and Corrections, he outlined these components with a six-part systematic definition. First, professions work was based on individual responsibility. The material and basis for their work came from science and their education. The professional is always working to shape this material into a goal. The methods of the professional should be replicable so that future professional can learn the same methods. A professional must be self-organized. Lastly, a professional will tend to be increasingly altruistic in motivation. ${ }^{17}$ This definition was complemented by case studies that used this definition to examine different occupations. ${ }^{18}$ Flexner believed that it was only through the university that true professionals were created. At university, students would learn the scientific knowledge important for their fields. Flexner's model was carried out in various other professions, like engineering, teaching, and nursing. ${ }^{19}$

${ }^{15}$ Michael Schudson, "The Flexner Report and the Reed Report: Notes on the History of Professional Education in the United States," Social Science Quarterly 55 (1974): 354.

${ }^{16}$ Schudson, "The Flexner Report and the Reed Report," 352-35.

${ }^{17}$ Abraham Flexner, "Is Social Work a Profession?," Research on Social Work Practice 11 (2001): 156.

${ }^{18}$ Brian Castellani and Frederic W. Hafferty. "The Increasing Complexities of Professionalism,"Academic Medicine 85 (2010): 290.

${ }^{19}$ William M. Sullivan, “Commentary: Expanding Flexner's Legacy Through New Understanding," Academic Medicine 85 (2010): 201. 
One can see how Flexner's idea of the construction of a professional is akin to the methods used in the sciences. Those methods provide a blueprint for how a researcher should conduct a scientific experiment and acquire knowledge. In a similar vein, Flexner created a systematic definition for how a person becomes a professional in their field. There are even methodological comparisons that can be observed between these two systems. The idea of an experiment needing to have falsifiability has a counterpart in Flexner's belief that the methods of a professional must have the ability to be replicated by others. The desire for psychoanalysis to be considered a professional discipline is one of the main reasons that many American psychoanalysts pushed so hard for lay analysis to be banned within the United States.

Kenneth Eisold, in his paper on the history of the New York Psychoanalytic Society, wrote that the Flexner Report influenced the American psychoanalysts because prior physicians managed to establish their own authority in their field. Therefore, they policed themselves and eliminated the quacks and charlatans from their discipline. ${ }^{20}$ The physicians distinguished themselves from the quacks by demarcating between the identity of the physician and the identity of the quack. The physicians established disciplinary authority by eliminating the quacks and charlatans, but without the quacks and charlatans this action could not have been taken. Most psychoanalysts in America wished to emulate the physicians of the Flexner Report in gaining control of their discipline and establishing a professional identity. The professionalization and scientism that the Flexner Report created for physicians became a key goal for psychoanalysts in New York. Flexner articulated a connection between medicine and other sciences in order to create the profession of "physician". In a similar fashion, American

${ }^{20}$ Kenneth, Eisold. "The Splitting of the New York Psychoanalytic Society and the Construction of Psychoanalytic Authority" International Journal of Psychoanalysis 79. (1998): 873. 
psychoanalysts thought they could achieve professional status if they tied themselves to medicine. ${ }^{21}$ Additionally, the fear of quackery and scientific charlatanism directed much of the future American arguments against lay analysis.

Freud's stance against medicine.

Just as the Flexner Report seemed to be the origin for the American position against lay analysis, there is a counterpoint: Freud sided with lay analysts. Freud developed a deep mistrust of medicine following the early practice of psychoanalysis in Vienna and Berlin. During Freud's early years in Vienna, the Viennese medical professionals criticized and ridiculed psychoanalysis. Prospective medical students were told by their teachers to ignore psychoanalytic theories and methods. ${ }^{22}$ Yet Freud himself started out his career in medicine as a student of neurology under Jean- Martin Charcot. ${ }^{23}$ Therefore, because Freud had come from the background of a medical science, his turn away from medicine is critical for understanding why he supported lay analysis.

In the early twentieth century, Freud tried to establish his young discipline in Vienna and other cities in surrounding countries. In 1905, he published three essays on the theory of sexuality. After reading these essays, groups of psychiatrists and neurologists, accused him of publishing pornographic stories about pure virgins. In 1907, Carl Jung, a member of Freud's inner circle, told Freud that psychiatrists in Germany were saying that they would never refer a

${ }^{21}$ Nathan G. Hale, The Rise and Crisis of Psychoanalysis in the United States: Freud and the American 1917-1985 (Oxford: Oxford University Press, 1995), 33.

${ }^{22}$ Lawrence Kubie, Practical and Theoretical Aspects of Psychoanalysis (New York: International Universities Press, 1950), 214. 52.

${ }^{23}$ Peter Gay, Freud: A Life for Our Time (New York: W.W. Norton \& Company, 1988), 
patient to Freud and that the psychoanalytic method was objectionable and unnecessary. ${ }^{24}$ Jung reported that one particular German psychiatrist, Gustav Aschaffenburg, explained that he explicitly forbade patients from mentioning anything remotely similar to Freudian sexual complexes. $^{25}$ In 1910, Freud received news from Ernest Jones that psychoanalysis was being attacked by psychiatrists and neurologists in both the United States and Canada. Jones said that James Jackson Putnam, an American neurologist, had spoken positively on behalf of psychoanalysis at a conference in Boston but most of the other psychiatrists spoke against it. ${ }^{26}$ Herman Nunberg, a psychoanalyst from the Vienna Psychoanalytic Society, described Freud's ideas as not well received by the medical community in Vienna. This negative reception directed towards Freud made him a lonely man because he enjoyed the company of others in discussing his ideas. $^{27}$

Freud's distaste for medicine's involvement in psychoanalysis solidified when he heard accounts of physicians employing psychoanalysis in a manner that Freud deemed incorrect. In 1910, responding to this alarming information, Freud wrote a short essay titled "On Wild Psychoanalysis." Freud began this essay with the story of a patient describing her previous psychoanalytic treatment by a physician. Following his description of the consultation with the patient, Freud dove into the problems of physicians practicing psychoanalysis. Freud's first criticism was that physicians did not understand some of the scientific principles of psychoanalysis, namely sexual life. Additionally, Freud criticized the physician's preference to

${ }^{24}$ Gay, Freud: A Life for Our Time, 194.

${ }^{25}$ Gay, Freud: A Life for Our Time, 194.

${ }^{26}$ Gay, Freud: A Life for Our Time, 196.

${ }^{27}$ Herman Nunberg, Minutes of the Vienna Psychoanalytic Society, Vol.1 1906-1908 (New York: International University Press, 1962), p. xix. 
diagnose an ailment as a neurological disorder. ${ }^{28}$ Freud stated that in discussion of sexual life, physicians focused too heavily on the physical act of coitus, when sexual life was much more complicated. Similarly, when diagnosing mental ailments, physicians only looked for physical neurological disorders without considering factors such as repression and resistance. ${ }^{29}$ Freud ended his essay with a very problematic statement which could be a clever jab at medicine but could also contradict his prejudice towards physicians: "Neither my friends and colleagues nor I feel comfortable about claiming a monopoly over the practice of this medical technique. ${ }^{\prime 30}$ Perhaps this is some sort of clever jab at medicine because if Freud was adamantly against medicine, then he would have wanted to have a strong control over the disciplinary direction but it is curious that he labeled psychoanalysis as a medical technique.

Following the poor response psychoanalysis received from various medical communities in Europe and America, Freud also began to develop disgust for many American psychiatrists and psychoanalysts. He believed that Americans were uncaring to detail in their methods. Freud's negative feelings towards Americans increased with accounts of new scandals involving poor usage of psychoanalysis. One of these scandals involved Andre Tridon, a French psychoanalyst living in America, who was known for his attempts to popularize psychoanalysis and expand psychoanalytic discussion in other disciplines. ${ }^{31}$ Ironically, Tridon was also a lay analyst. However, in the early 1920s, Tridon plagiarized some of Freud's material in a book.

\footnotetext{
${ }^{28}$ Sigmund Freud, Wild Analysis, trans. Alan Bance (London: Penguin Books, 2002), 2.

${ }^{29}$ Freud, Wild Analysis, 5.

${ }^{30}$ Freud, Wild Analysis, 8.

${ }^{31}$ Hale, Rise and Crisis, 69.
} 
Even worse, Tridon claimed that Freud had approved and even praised his work. ${ }^{32}$ When Freud learned of Tridon's work he was outraged and he proclaimed Tridon to be a thief. He then went on to say that this type of academic thievery seemed to be a common occurrence in the United States. ${ }^{33}$ Freud's poor opinion of Americans continued until his death in 1939. In this chapter, I have provided a brief synopsis of some of the foundations for the American psychoanalyst position against lay analysis. Additionally, I have shown how Freud became embittered against the role of medicine in psychoanalysis and how he was drawn to support lay psychoanalysis. The next two chapters of this essay explore the two sides of this argument in greater detail. In these chapters, readers can see how the events and their outcomes described in this chapter manifested within the context of the conflict.

\footnotetext{
${ }^{32}$ Hale, Rise and Crisis, 69-71.

${ }^{33}$ Hale, Rise and Crisis, 72.
} 


\section{Chapter III: Arguments for Allowing the Practice of Lay Analysis}

The ban of lay analysis in New York, Theodore Reik's trial, and Freud's response.

As stated earlier, the results of the Flexner Report radically changed the expectations for training in medical disciplines. With new policies and uniform curriculums in universities, the American medical community watched carefully for any potential cases of quackery or pseudoscientific charlatanism. As a result, American psychoanalysts became more wary of their image as an emerging scientific discipline. Initially, American analysts had traveled oversea to Europe to obtain training, but now training institutions began to form on American soil. Modeled on the structure of the Berlin Institute, the New York Psychoanalytic Society was established in 1911 by A.A Brill. ${ }^{1}$ Brill was inspired to practice psychoanalysis after hearing Freud's Clark University Lectures in $1909 .^{2}$ In the next twenty years, other psychoanalytic institutes developed in cities such as Chicago, Boston, and Baltimore. ${ }^{3}$ These institutes employed analysts such Smyth Ely Jeliffe, who were taught in Europe and returned to America to teach the next generation of psychoanalysts. As the general populace became more aware of psychoanalysis,

\footnotetext{
${ }^{1}$ Nathan G. Hale, The Rise and Crisis of Psychoanalysis in the United States: Freud and the Americans 1917-1985 (Oxford: Oxford University Press, 1995), 30-31.

${ }^{2}$ Nathan G. Hale, Freud and the Americans: The Beginnings of Psychoanalysis in the United States 1876-1917 (New York: Oxford University Press, 1971), 5. 24.

${ }^{3}$ Robert Wallerstein, The Question of Lay Analysis (Hillsdale: The Analytic Press, 1998),
} 
many American analysts became much more concerned with promoting their work as medically sound and scientific. ${ }^{4}$ However, as historian Nathan G. Hale points out, American psychoanalysis was not well received by some members of the neurological and psychiatric communities. The professionalizing reforms promoted by the Flexner Report made members of the neurological and psychiatric communities sensitive to anything that could be related to quackery. Attempts from psychoanalysts to start a psychoanalytic clinic in New York City were rejected by the city's medical authorities almost immediately. The Flexner Report had brought accusations of quackery and inappropriate lay practice to the forefront of physicians' concerns. These concerns caused American institutes to discourage and in the case of the New York Psychoanalytic Institute even ban lay analysts from practicing psychoanalysis. ${ }^{5}$

In 1926, the New York state legislature banned the practice of medicine without a medical degree. ${ }^{6}$ Shocking to Freud was the rumor that psychoanalysts from the New York community had campaigned for the inclusion of psychoanalysis in this ban. According to Sandor Ferencizi, A.A Brill led the charge for this legislation against lay analysis. ${ }^{7}$ The official policy was that non-medical analysts could not practice psychoanalysis unless it was for furthering work in their own fields, such as anthropology, sociology, or theology. ${ }^{8}$

After the legislative decisions made in New York to ban the practice of lay analysis, the psychoanalytic community experienced another controversy. Theodore Reik, a lay analyst

\footnotetext{
${ }^{4}$ Hale, Rise and Crisis, 33.

${ }^{5}$ Hale, Rise and Crisis, 33

${ }^{6}$ Hale, Rise and Crisis, 33.

${ }^{7}$ Hale, Rise and Crisis, 33.

${ }^{8}$ Hale, The Rise and Crisis, 34
} 
practicing in Vienna, was charged with quackery by an American client. ${ }^{9}$ In a month following the charges brought against Reik, Freud published The Question of Lay Analysis which presented an argument for allowing the practice of lay analysis to continue. This publication brought the issue of lay analysis to the forefront of psychoanalytic discourse in both Europe and America.

\section{The Question of Lay Analysis.}

Freud had always been in favor of lay analysis since the early formation of psychoanalysis. When Freud first started his Psychological Wednesday Evening Society, of the twenty two listed members, six of them had come from non-medical backgrounds. ${ }^{10}$ Therefore, it was only natural for Freud to rush to the side of Theodore Reik when he was charged with quackery in Vienna. Freud's publication of The Question of Lay Analysis was in response to the charges brought against Reik. Freud intended to show how lay analysts like Reik had a place within the psychoanalytic community.

The Question of Lay Analysis is structured similar to a Platonic dialogue in which Freud explains psychoanalysis to an "impartial listener" who is curious about it. ${ }^{11}$ In the first portion of the book, Freud explains the basic concepts of psychoanalysis. In the final three chapters, Freud argues for the value of lay analysis. His strongest point is summed up in this passage:

The preparation for analytic practice is no simple and easy matter; the work is hard and the responsibility heavy, But, anyone who has undergone such a discipline, has been analyzed, has grasped the psychology of the unconscious as it is known today, has become versed in the scientific aspects of sexuality, and has

\footnotetext{
${ }^{9}$ Kurt Eissler, Medical Orthodoxy and the Future of Psychoanalysis (New York: International Universities Press, 1965), 35-37.

${ }^{10}$ Wallerstein, Lay Analysis: Life Inside the Controversy, 4.

${ }^{11}$ Sigmund Freud, The Question of Lay Analysis (New York: W.W. Norton \& Company, 1927), 17.
} 
learned the delicate technique of psychoanalysis, the art of interpretation, the way to combat resistance, and to manage the transference-that person is no longer a layman in the field of psychoanalysis. ${ }^{12}$

Essentially, Freud believed that if someone completed the curriculum from a psychoanalytic institute then they were not a lay analyst. This passage shows that the label of "lay analysis" is one being imposed by the medical analysts. Furthermore, Freud argued practitioners of medicine did not have jurisdiction to condemn a non-medical analyst as being a quack. Similarly, Freud criticized the use of the term "quack" to describe lay analysts. For Freud, quacks were people who treat patients without proper understanding of the psychoanalytic knowledge or the ability to use it. Indeed, Freud believed that not lay analysts but doctors were the main source of quackery in psychoanalysis. ${ }^{13}$ Clearly, Freud still harbored his fears of the "wild" psychoanalytic physicians who had been practicing in America during the early twentieth century.

Freud designated psychoanalysis as a psychological and not a psychiatric discipline because psychiatry looks for physical causes of neurotic ailments while psychoanalysis is a treatment for ailments caused by the unconscious. ${ }^{14}$ Freud used this distinction between psychology and psychiatry to assert that for pathological purposes, a patient should consult a physician first to diagnose any physical causes for mental illness. ${ }^{15}$ Even though Freud disapproved of medical control over psychoanalysis, he still believed that medicine was relevant to the treatment of neurotics. However, he did not want psychoanalysis to fall under a medical

\footnotetext{
${ }^{12}$ Freud, The Question of Lay Analysis, 89.

${ }^{13}$ Freud, The Question of Lay Analysis, 92.

${ }^{14}$ Freud, The Question of Lay Analysis, 93.

${ }^{15}$ Freud, The Question of Lay Analysis, 113.
} 
monopoly. Finally, Freud provided a model for the ideal psychoanalytic institute in which these institutes would share much of the same curriculum that any medical facility would teach, including subjects such as biology and the science of sex. But in addition to those courses, analysts would also be taught material from disciplines outside of medicine such as mythology, history of civilization and the psychology of religion and literature. ${ }^{16}$ To Freud, psychoanalysis had a lot to gain from the inclusion of these so called "lay" subjects because it would allow psychoanalysis to bridge out and connect multiple disciplines with each other.

The 1927 Symposium on Lay Analysis: arguments from the lay analysts.

Freud's publication of The Question of Lay Analysis generated much discussion within the psychoanalytic community. Thus, later in 1927, the IPA held a symposium at one of their conferences to address the debate surrounding lay analysis. ${ }^{17}$ This conference included both European and American analysts of both medical and lay training. It provided a venue where both sides of the debate emerged. Of the twenty-six analysts at the conference, ten of them agreed with Freud's position on lay analysis, eleven analysts were opposed to the idea of lay analysis, and five were undecided. I consider first, in the remainder of this chapter, the arguments for lay analysis.

Hanns Sachs was the head of training at the Berlin Psycho-Analytical Institute which meant that he was in charge of all issues surrounding psychoanalytic education and training for that institute. He was one of the four lay analysts who presented at the symposium. His contribution to the symposium centered on using his own experience as a training analyst to

\footnotetext{
${ }^{16}$ Freud, The Question of Lay Analysis, 118.

${ }^{17}$ Wallerstein, Lay Analysis: Life Inside the Controversy, 16.
} 
provide a practical argument instead of a polemical one. Sachs stated that he only took on a few therapeutic cases because he was busy with the training of new analysts; however, he argued that if he had the qualifications to train analysts then he must also have the skills to treat neuroses. ${ }^{18}$ While this may have seemed justifiable to Sachs and other lay analysts, it might not have sat well with medical analysts; especially, when the topic of training was contested area by the medical analysts and lay analysts.

Theodore Reik was another lay analyst who had been invited to participate in the symposium. Reik questioned the definition of the layman but in different way than Freud had addressed in his book. Reik believed that a lay analyst was a person who had no understanding of psychoanalysis and that the term itself was quite ambiguous. ${ }^{19}$ Thirty years before this symposium, everyone had been a lay analyst in psychoanalysis because it was such a young discipline. While there had been a few scientific forerunners for psychoanalysis, the majority of influential disciplines had been outside of the natural sciences and included philosophers such as Plato, Schopenhauer, and Nietzsche as well as writers and pastors. ${ }^{20}$ Reik was very interested in how philosophy and religious studies could be used in psychoanalysis and he would pursue this topic in his future work.

Franz Alexander was another advocate for lay analysis. Alexander argued that at the current time, psychoanalysis' position with regard to medicine was undefined and that

${ }^{18}$ Hanns Sachs, in the "Discussion: Lay Analysis," International Journal of Psychoanalysis 8 (1927): 199. For the remainder of the paper, I will refer to other sources from the symposium in the format of Name, Discussion: Lay Analysis, and Page Number.

19 Theodore Reik, "Discussion: Lay Analysis,” 242.

${ }^{20}$ Reik, "Discussion: Lay Analysis," 243. 
psychoanalysis was "an independent science of mental processes." 21 Psychoanalytic training required focus on promoting psychoanalytic concepts instead of preliminary medical training. Alexander posited that academic medicine had diminished psychological knowledge, and that lay analysts oftentimes surpassed medically trained analysts in treating the "ills of humanity.",22 Nevertheless, psychoanalysis could aid medicine by helping doctors realize the strong connection between the personality and the human body, thus unifying the mind and the body together as a single organism. ${ }^{23}$ Alexander's position on this debate is fascinating because, after he emigrated to the United States, he reversed his position on lay analysis, as we will see later.

Geza Roheim, who practiced psychoanalysis in conjunction with anthropology, composed his statement to answer the question of how did lay analytic subjects contribute to psychoanalysis in general. ${ }^{24}$ This was a question that medical analysts asked throughout the symposium. $^{25}$ Roheim believed that to answer this question one had to understand how psychoanalysts were currently trained; not through reading or logical reasoning, but through experience. $^{26}$ What Roheim meant by experience was a session where the prospective analysts is psychoanalyzed by another analyst. All psychoanalysts had to go through this experience, but why would psychoanalysts want to limit how psychoanalysis was used after the training analysis

${ }^{21}$ Franz Alexander, "Discussion: Lay Analysis,” 223.

${ }^{22}$ Alexander, "Discussion: Lay Analysis," 224.

${ }^{23}$ Alexander, "Discussion: Lay Analysis," 225.

${ }^{24}$ For more on Geza Roheim and his work with psychoanalysis and anthropology consult GezaRoheim, Psychoanalysis and Anthropology: Culture, Personality, and the Unconscious. (New York: International University Press, 1950).

${ }^{25}$ Geza Roheim, "Discussion: Lay Analysis,” 245.

${ }^{26}$ Roheim, “Discussion: Lay Analysis,” 244. 
was complete? If psychoanalytic training was limited to only those students who came from medical backgrounds, then a whole branch of psychoanalytic discussion and practice would be cut off. Roheim argued that this limitation was unacceptable. He felt that psychoanalysis had the unique position to connect other disciplines together in ways that at the time had not yet been thought of. Psychoanalysis was "the spiritual bond" that could connect scientific knowledge and lay analysis was integral for this disciplinary connection to occur. ${ }^{27}$

Robert Walder came to the symposium from Vienna, a city whose psychoanalytic community was divided on the subject of lay analysis. Several analysts spoke against lay analysis as well as in affirmation of it. Walder agreed with Freud that in terms of diagnoses, a patient should consult first with someone from a medical background. However, he felt that this did not have to be a medical psychoanalyst per se but just someone possessing a medical background. ${ }^{28}$ Additionally, Walder argued that the definition for mental illness and neuroses had changed from being solely physical ailments to having non-physical characteristics, including "character, personality, or abilities."29

The symposium concluded with a statement presented by Freud, a kind of addendum to The Question of Lay Analysis. In it, Freud reaffirmed that the subject material brought by lay analysis was as just as important as the material brought from medical and biological backgrounds. ${ }^{30}$ Furthermore, psychoanalysis was a "part of psychology—not even of medical psychology in the old sense of the term, or of the psychology of morbid processes, but, simply,

${ }^{27}$ Roheim, "Discussion: Lay Analysis," 245.

${ }^{28}$ Robert Walder, “Discussion: Lay Analysis,” 275.

${ }^{29}$ Walder, "Discussion: Lay Analysis," 274.

${ }^{30}$ Sigmund Freud, "Concluding Remarks on the Question of Lay Analysis," International Journal of Psychoanalysis 8 (1927): 392-401. 
of psychology.. ${ }^{31}$ He then made a comparison of psychoanalysis to physics. X rays were used for medicine but they remained in the domain of physics. In a similar fashion, psychoanalysis could be applied to medicine but yet remain its own discipline. ${ }^{32}$ He finished off his statement by saying that he understood the American problems with lay analysis were based on practicality. After all, American physicians had been plagued by mischief caused by quackery, but their resolution to the problem was impractical. It would be better if lay analysts were accepted, trained, and allowed to contribute to psychoanalysis. ${ }^{33}$ This would reduce the number of cases of quackery because there would not be as many deterrents to training. In this sense, Freud was arguing that the real problem was not lay analysts but was the lack of a standardized training curriculum.

The aftermath of the 1927 Symposium and the years following for lay analysts.

After the symposium, Freud felt little had been accomplished by his work in The Question of Lay Analysis. He later told the Swiss analyst Raymond de Saussure that the Americans cared only for themselves and not for psychoanalysis as a whole. ${ }^{34}$ However, he did have the satisfaction of instilling fear in the Americans when they heard the rumor that he was thinking of cutting all ties with American institutes. Brill wrote to him asking if the rumors were true but Freud responded that while he was extremely unhappy with the American position on lay analysis he was not going to force them out. This seemed to have reassured Brill somewhat

${ }^{31}$ Freud, "Concluding Remarks," 393.

${ }^{32}$ Freud, "Concluding Remarks,” 393.

${ }^{33}$ Freud, "Concluding Remarks," 397.

${ }^{34}$ Peter Gay, Freud: A Life of Our Time (New York: W.W. Norton \& Company,1988), 500. 
and in a sign of good faith he pushed for allowing lay analysts to be able to work with children. ${ }^{35}$ Child analysis would become one of the only ways that lay analysts could find positions in American psychoanalytic institutes. Kurt Eissler, a proponent of lay analysis, wrote that child analysis had been primarily practiced by lay analysts in the past. ${ }^{36}$ In this sense, Brill's support for allowing lay analysts to practice child psychoanalysis was an attempt to appease Freud but also keep lay analysts to a lower status within the psychoanalytic community.

Esther Meneker, wife of psychoanalyst William Meneker, described her journey with child analysis in America in her article "Early Struggles in Lay Psychoanalysis: New York in the Thirties, Forties, and Fifties." Meneker, unlike her husband, did not have any medical training, but thanks to Brill, she was allowed to practice child analysis. She explained that initially she worked with children but later moved on to taking on adult clients. Therefore, she was able to bend the rules that surrounded banning lay analysts from membership in the New York Psychoanalytic Society. ${ }^{37}$ Meneker also mentions that during the late 1930s, Reik was holding small discussion groups of lay analysts, thereby allowing the circulation of lay analytic work to continue. $^{38}$

Reik continued his work in psychoanalysis after the symposium on lay analysis. In an article published in1929 in International Journal of Psychoanalysis, Reik contended that overemphasis of the therapeutic aspects of psychoanalysis led to restrictions on the scientific achievements of psychoanalysis and that treating mental illness required an acute awareness of

${ }^{35}$ Gay, Freud: A Life of Our Time, 500.

${ }^{36}$ Eissler, Medical Orthodoxy and the Future of Psychoanalysis, 214.

${ }^{37}$ Esther Meneker, "Early Struggles in Lay Psychoanalysis: New York in the Thirties, Forties, and Fifties" The Psychoanalytic Review 75 (1988): 373-379.

${ }^{38}$ Meneker, "Early Struggles in Lay Psychoanalysis,” 378. 
cultural institutions. ${ }^{39}$ These institutions included ideas such as morality or religion. ${ }^{40}$

Furthermore, he provided examples of how knowledge of religions can help treat a mentally ill patient. In one example, he described a patient who had neurotic outbursts concerning religious subjects; without knowledge of those religious subjects, a psychoanalyst could not effectively treat that patient. ${ }^{41}$ Clearly, Reik still believed that lay analysis could contribute to the psychoanalytic method. In this case, knowledge of religion was able to help psychoanalysts treat mental illness. ${ }^{42}$

Reik went through trying times before he was finally able to emigrate to America. In 1934, he attempted to move to England but was rejected by Ernest Jones, the prominent British psychoanalyst at that time. Therefore, he moved to Holland and lived there until he felt that it was no longer safe to live in Europe. In 1938, Reik left Holland and arrived in the United States without any financial stability. With the help of financial support from friends, Reik lived in an apartment rent free and was able to establish a practice in New York. In spite of this, Reik was extremely frustrated with the New York Psychoanalytic Society. While he, like other prominent European lay analysts, had been grandfathered into the society, it was still frustrating for Reik to practice psychoanalysis under the watchful and critical gaze of his American medical colleagues. Members of the New York Psychoanalytic Society tried to bargain with Reik to accept a minor lecture role but he considered this an insult. Consequently, the relationship between both parties

${ }^{39}$ Theodore Reik, "The Therapy of the Neuroses and Religion," International Journal of Psychoanalysis 10 (1929): 292-302.

${ }^{40}$ Reik, "The Therapy of the Neuroses and Religion," 293.

${ }^{41}$ Reik, "The Therapy of The Neuroses and Religion, 297.

42 Theodore Reik, "The Therapy of the Neuroses and Religion" International Journal of Psychoanalysis 10 (1929): 292-302. 
was irreparably damaged. ${ }^{43}$ Initially, Reik believed he would be respected as one of Freud's closest colleagues and that respect would allow him to enlighten those who had never met Freud. ${ }^{44}$ Reik later said that at one point the New York Psychoanalytic Society even tried to bribe him into not practicing psychoanalysis. ${ }^{45}$ Subsequently, Reik left and pursued his own practice with the intent to help other lay analysts in America.

There are several conclusions that can be drawn from the arguments made for allowing lay analysis to continue. Many of these arguments center upon what kinds of training and knowledge were most valuable for the psychoanalysts. Freud sees psychoanalysis as a discipline that can transcend being only a therapeutic treatment. This is one of the stark contrasts between the two sides. Freud saw psychoanalysis as a potential bridge between many different disciplines. This argument was echoed by Geza Roheim's assertion that psychoanalysis had the ability to create a spiritual bond between different branches of scientific knowledge. If Freud, Roheim, and others believed that psychoanalysis had multidisciplinary components, then it is obvious why they did not want psychoanalysts to be limited to medical training. However, this did not fully answer the question about what was the best training for the analyst. As Freud saw it, if one completed the courses in a psychoanalytic training institute and underwent a training analysis, then that person had the ability to practice psychoanalysis and was not a lay analyst. Americans medical analysts, on the other hand, stressed that the best way for psychoanalysis to become a professional discipline was for it to try and attach itself to medicine and the way medicine was learned and practiced in America. This training required a medical education and

\footnotetext{
${ }^{43}$ Murray H. Sherman. “Theodore Reik and Lay Analysis,” The Psychoanalytic Review 75 (1988): 381-391.

${ }^{44}$ Sherman, "Theodore Reik and Lay Analysis," 385.

45 Sherman, "Theodore Reik and Lay Analysis," 385.
} 
a medical license. Once that training was complete, then a psychoanalyst could provide evidence proving that they could treat the mentally ill. The arguments of lay and medical analysts provide the two conflicting ideas that the sides had for the disciplinary identity of psychoanalysis. The next chapter explores the arguments of the medical analysts and how they believed that psychoanalysis was best suited as a medical discipline. 


\section{Chapter IV: Arguments for the Integration of Psychoanalysis with Medicine as well as the Ban of Lay Analytic Practice.}

The medical arguments made at the 1927 symposium on lay analysis.

There was a strong contingent of psychoanalysts who presented against lay analysis at the 1927 symposium. Among the analysts were C.P. Oberndorf, A.A Brill, and Karen Horney. Their arguments covered topics such as the benefits that psychoanalytic diagnoses could receive from medical training as well as how lay analysis was hindering psychoanalysis' growth as a treatment method. Oberndorf, a psychoanalyst from New York, immediately attacked the structure and argument of Freud's Question of Lay Analysis. He compared it to a sore that had been prematurely operated upon, when it would have been much simpler to leave it alone and let it heal itself. Oberndorf's analogy was structured in medical concepts and it appears to be a clever poke at Freud's work. ${ }^{1}$ However, Oberndorf's argument was much more serious. In his initial view of the development of psychoanalysis in the United States, Oberndorf stated that most of the work had been done by physicians themselves. Additionally, he reasserted the fragile ground that psychoanalysis stood upon under the scrutiny cult like disciplines received in the United States.

\footnotetext{
${ }^{1}$ C.P. Oberndorf, "Discussion: Lay Analysis,” 201-202.
} 
Oberndorf's argument for medical psychoanalysis grew from his idea that medical training was invaluable to the practice of psychoanalysis. In his words, "I cannot recall a single case where in the evaluation of symptoms I have not been compelled to fall back upon medical training and a knowledge of the functioning of the body in health and in disease." ${ }^{2}$ Oberndorf believed that medical knowledge could greatly increase the efficiency of diagnoses in psychoanalytic treatment, a point shared by future medical analysts.

Oberndorf went a step further to address Freud's anti-medical position by saying that psychoanalysis was as interrelated to medicine as chemistry was to physics. ${ }^{3}$ Oberndorf claimed that psychoanalysis had received little benefit from non-medical arts and sciences. This was contrary to the argument made by Freud in The Question of Lay Analysis in which Freud argued that psychoanalysis profited from non-medical disciplines because there were many nonphysiological factors within a mental illness. ${ }^{4}$ Oberndorf reinforced the American position of keeping psychoanalysis away from cults and quacks. ${ }^{5}$ This statement was the first that was in direct opposition to lay psychoanalysis. All the subsequent statements from American analysts were opposed to the practice of lay analysis as well. ${ }^{6}$ Robert Wallerstein, a historian of psychoanalysis and a psychoanalyst himself, considers Oberndorf's piece as one of the most

${ }^{2}$ Oberndorf, "Discussion: Lay Analysis," 203.

${ }^{3}$ Oberndorf, "Discussion: Lay Analysis," 206.

${ }^{4}$ Sigmund Freud, The Question of Lay Analysis (New York: W.W. Norton \& Company, 1927), 118.

${ }^{5}$ Oberndorf, "Discussion: Lay Analysis," 205.

${ }^{6}$ Robert Wallerstein, Lay Analysis: Life Inside the Controversy (Hillsdale: The Analytic Press, 1998), 16-17. 
eloquent of the symposium. ${ }^{7}$ Oberndorf brought up a key concern for the advocates of lay analysis by exposing how medical knowledge greatly improved an analyst's ability to diagnose possible physical symptoms that caused neuroses.

Ernest Jones, who was a member of Freud's inner circle, also shared Oberndorf's point on diagnoses in his statement at the symposium. However, while Jones believed that medical training could improve an analyst's ability to treat neuroses he also thought that psychoanalysis should not limit itself by banning lay analysis. ${ }^{8}$

Karen Horney, a German psychoanalyst working in Berlin, also agreed that psychoanalysis would gain benefits from medicine in the area of diagnoses. She argued that medical knowledge would allow analysts to judge somatic symptoms better, as well as be able to review other medical opinions that the patient had received before analysis. ${ }^{9}$ What Oberndorf, Jones, and Horney all agreed on was that psychoanalytic diagnoses would greatly benefit from the analyst having some sort of exposure to medical training. How much and how extensive this medical training needed to be was open to debate. Nevertheless, it was an important facet for proponents of medical analysis to show how physical symptoms played a role in mental illness.

A.A. Brill was unable to attend the symposium so he sent his argument in a letter. Brill's letter was a concise review of Freud's The Question of Lay Analysis. Like his American colleague Oberndorf, Brill believed that psychoanalysis was an integral part of medicine. However, Brill's was more tactful than Oberndorf in presenting his counterpoints to Freud's

\footnotetext{
${ }^{7}$ Wallerstein, Lay Analysis: Life Inside the Controversy, 17.

${ }^{8}$ Ernest Jones, "Discussion: Lay Analysis," 183.

${ }^{9}$ Karen Horney, “Discussion: Lay Analysis,” 257-258.
} 
arguments. Indeed, he even refers to Freud several times without name but as the "master."10 Nevertheless, Brill stated that he used to blindly follow Freud's advice but it was through his own experience and knowledge that he was able to trust his own conclusions even if they were opposed to Freud's. Brill believed that psychoanalysts needed to have some preliminary knowledge of anatomy, physiology, bacteriology, and chemistry. This statement is not unlike the argument that Flexner made in his report about doctors requiring familiarity with the sciences. Brill pointed out that while this was cumbersome to the training process of a prospective analyst, it was just as cumbersome for medical students. ${ }^{11}$ Brill included this statement to respond to the criticism from lay analysts that if psychoanalysis aligned with medicine then it would take too long to train future analysts.

Another analyst who believed in medical analysis was Wilhelm Reich. Reich came to the symposium from the Vienna. Reich believed that psychoanalysts benefited from working with other medical disciplines. He argued that psychoanalysis' development as a mental science had been greatly hindered by the work of lay analysts. ${ }^{12}$ Reich pointed out that Freud himself had said that psychoanalysis would eventually come to a moment when the "organic" aspects of psychoanalytic treatment would form a nucleus for further psychoanalytic study. ${ }^{13}$ Reich used the term organic to describe physical elements within the body that triggered mental disorders such as the idea of the libido being both biologically and mentally influenced. ${ }^{14}$ Lay analysis

\footnotetext{
${ }^{10}$ A.A Brill, "Discussion: Lay Analysis,” 220.

${ }^{11}$ Brill, "Discussion: Lay Analysis," 220.

${ }^{12}$ Wilhelm Reich, "Discussion: Lay Analysis,” 251.

${ }^{13}$ Reich, "Discussion: Lay Analysis," 252.

${ }^{14}$ Reich, "Discussion: Lay Analysis," 252.
} 
threatened this future for psychoanalysis because there would be a large group of analysts who were unprepared to work with physical elements of treatment. Reich again countered Freud's statements, arguing that psychoanalysis received even more complicated objection from philosophers. Philosophy was one of the subjects Freud thought was important for training analysts. ${ }^{15}$ Finally, Reich argued that the skills analysts learned from medical training prepared them to handle patients in a better manner than a lay analyst who did not have access to some branches of knowledge obtained through medical education. ${ }^{16}$ While Reich's final statement is somewhat callous and unsubstantiated, it points to a greater problem within psychoanalysis. Namely, what was the best way for psychoanalysis to be learned, taught, and eventually practiced.

Karen Horney dove deeper into this problem with her argument. Horney tackled the issue of lay analysis using a reductive method. She began with a single question: "what constitutes the best preliminary study for training, and that not for the psycho-analyst in general, but for the therapeutic psycho-analyst?"17 Horney distinguished between therapeutic analysts and other types of psychoanalysts. Analysts who were using psychoanalysis for anthropology or sociology obviously would not care as much for therapeutic concepts. This distinction between the therapeutic psychoanalyst and the social science analyst brings up interesting points in Horney's argument, especially since she believed it was possible for psychoanalysis to have two separate practitioners of the psychoanalytic method. In Horney's later work she explored non-

\footnotetext{
${ }^{15}$ Reich, "Discussion: Lay Analysis," 253.

${ }^{16}$ Reich, "Discussion: Lay Analysis," 254.

${ }^{17}$ Horney, "Discussion: Lay Analysis," 255.
} 
medical factors such as culture and how they were an undercurrent to mental disorders. ${ }^{18}$ Nevertheless, the question remained over what was the best preliminary study for therapeutic psychoanalysis: "which of the schools of study at present available seems to us the best as a foundation for the special training of the therapeutic analyst?"19 Horney further reduced these schools of study to the philosophical and medical. Both schools of thought had a surplus of unnecessary knowledge, but Horney believed that the knowledge from the medical school would overall have a larger benefit to a future analyst. ${ }^{20}$

The symposium on lay analysis did not resolve any major problems surrounding the practice of lay analysis. Instead, the further discord that came out of the conference was the threat of American separation from the IPA. For the next ten years, Ernest Jones scrambled to find a way for both the IPA and the APsaA to come to a settlement with each other. ${ }^{21}$

The growing breach between European and American analysts.

Following the 1927 symposium on lay analysis, the International Training Committee for the IPA proposed a resolution for compromise between medical and lay analysts. First, the importance of medical education would be heavily stressed upon future analysts by their local societies. However, no analyst would be turned away solely because of lack of medical education, as long as they had a preliminary scientific training. Second, analysts had to respect the training prerequisites set up by their country of origin as well as those regulations in the place

${ }^{18}$ Karen Horney, New Ways in Psychoanalysis (New York: W.W. Norton \& Company, 1939), 176-177.

${ }^{19}$ Horney, “Discussion: Lay Analysis,” 255.

${ }^{20}$ Horney, "Discussion: Lay Analysis" 256.

${ }^{21}$ Wallerstein, Lay Analysis: Life Inside the Controversy, 34-46. 
the analysts were currently was studying. ${ }^{22}$ This resolution was vehemently opposed by the American delegation and voted down. ${ }^{23}$ A new committee, headed by Sandor Rado, formed to try and find a new solution. ${ }^{24}$

At this point, two prominent figures in the psychoanalytic community worked to heal the breach between the European and American institutes. The first was Max Eitingon, president of the IPA during 1929, who tried to find an accommodation that favored the European position of allowing lay analysis. The other was Ernest Jones, who attempted to cater to the American's position against lay analysis. ${ }^{25}$ As president of the IPA from 1932 to 1949 , Jones was an advocate for the American position in this conflict. In a letter to Theodore Reik in 1933, Jones wrote that Reik was contradicting himself by saying that he would accept patients from British medical analysts but he did not need them. Jones believed that Reik could round up his own patients but Reik would not have enough to sustain an adequate income. ${ }^{26}$

This pattern of IPA congresses meeting and not finding a compromise between lay and medical analysts continued through the 1930 s during, the $13^{\text {th }}$ congress in 1934 and the $14^{\text {th }}$ congress in 1936. During these sessions, the American and European delegations reached no compromise. The American delegation remained adamant in their stance against lay analysis,

22 "Bulletin for the IPA," International Journal of Psychoanalysis 9, (1928): 140, in Wallerstein, Lay Analysis: Life Inside the Controversy, 29.

${ }^{23}$ Wallerstein, Lay Analysis: Life Inside the Controversy, 29.

${ }^{24}$ Wallerstein, Lay Analysis: Life Inside the Controversy, 30.

${ }^{25}$ Wallerstein, Lay Analysis: Life Inside the Controversy, 32.

${ }^{26}$ Jones to Reik, December 20, 1933, in Wallerstein, Lay Analysis, 34. 
while the Europeans were mostly concerned with finding a compromise to appease the Americans and allow lay analysis to continue. ${ }^{27}$

As scholarship in the history of psychoanalysis has shown, there had always been a strong connection between the American and European psychoanalytic communities. ${ }^{28}$ From 1900-1920, Europe was the center for psychoanalytic discourse and therefore many American psychoanalysts traveled to Europe in order to receive training. During the 1930s, America became the center of psychoanalytic study. This was largely due to the growing threat of warfare in Europe. During the 1930s, European refugee analysts came to the United States to find a safe and secure living environment. ${ }^{29}$ Unfortunately, this was not the case for many refugee analysts because at the time, America and other nations were undergoing the Great Depression. The Depression exacerbated the conflict between lay and medical analysts because many refugee analysts coming to Europe were lay. These refugee analysts were coming to the United States with the expectation that the American psychoanalytic organizations would help them find work. ${ }^{30}$ Like many Americans struggling for work at that time, psychoanalysts were hard pressed to find clients and the threat of losing these clients to refugee lay analysts was unacceptable to many American medical analysts. ${ }^{31}$ The increased immigration of analysts

${ }^{27}$ For a full detailed explanation of the events of the $13^{\text {th }}$ and $14^{\text {th }}$ IPA congresses consult Wallerstein, Lay Analysis: Life Inside the Controversy, 35-44.

28 For more information on the relations between European and American psychoanalysts consult Nathan G. Hale's Rise and Crisis of Psychoanalysis: Freud and the Americans or International Relations in Psychiatry edited by Volker Roelcke, Paul J. Weindling, and Louise Westwood.

\footnotetext{
${ }^{29}$ Hale, Rise and Crisis, 115.

${ }^{30}$ Hale, Rise and Crisis, 116.

${ }^{31}$ Hale, Rise and Crisis, 117.
} 
further intensified conflict. Ives Hendricks, an American psychoanalyst, stated that these conflicts were now "Jews against gentiles, American against European, old against young."

While it was difficult for many of the refugee analysts to find work upon arriving in America, there were some analysts who integrated into American psychoanalytic institutes and universities right away. Franz Alexander and Sandor Rado were both European analysts who had experience working in European institutes and later found jobs in American institutes. Franz Alexander moved to the United States and became a professor at the University of Chicago in 1931. Alexander is an interesting figure in this debate because he started out as a proponent of lay analysis; however, following his immigration to the United States, he reversed his views. ${ }^{33}$ In 1932, Alexander wrote The Medical Value of Psychoanalysis, which became a key text in the argument for inclusion of psychoanalysis in medicine. Alexander began his book by delineating the problematic position of considering psychoanalysis to be its own distinct discipline and that this position jeopardized psychoanalysis joining with medicine. ${ }^{34}$ Alexander posited that the processes and ailments of both mental and physical nature were related to each other and that the body should be looked at as a unified psychobiological entity. ${ }^{35}$ Previously, psychoanalysis had only contributed to psychiatry through insight into psychodynamic structure. ${ }^{36}$ These contributions had taken the form of the theories of Oedipus complex, instinct theory, infantile sexuality, and others discovered by Freud. Alexander theorized that psychoanalysis was capable

${ }^{32}$ Ives Hendricks to Smyth Ely Jelliffe, Jan. 16, 1933 in Hale, Rise and Crisis, 115.

${ }^{33}$ Wallerstein, Lay Analysis: Life Inside the Controversy, 67.

${ }^{34}$ Franz Alexander, The Medical Value of Psychoanalysis (New York: International Universities Press, Inc, 1932), 17.

${ }^{35}$ Alexander, The Medical Value of Psychoanalysis, 19.

${ }^{36}$ Alexander, The Medical Value of Psychoanalysis, 105. 
of aiding medicine in other fields besides what it had already done in psychodynamic structure and psychopathology. Furthermore, Alexander pointed out how psychoanalysts already contributed to the understanding of the body through their work in studying of psychosomatic reactions. $^{37}$

Alexander finished with a discussion of how to integrate psychoanalysis into the medical education programs of universities. Using his time as a professor at the University of Chicago as an example, Alexander posited that psychoanalysis could be successfully incorporated into the study of medicine in three parts. The first two parts would be taught at the undergraduate level, while the final part would be a graduate level course. Initially, a student would learn basic elementary psychoanalytic concepts in conjunction with their studies of anatomy and physiology. The second part of the course material would cover theories of general psychiatry including psychoanalytical psychopathology. The final graduate level course would be training in psychoanalysis during an internship at a psychiatric hospital. This would include the training analysis as well as theoretical and practical training. ${ }^{38}$ Alexander continued to stand for medical analysis throughout the 1930s. He went on to write several more articles on the relationship between psychoanalysis and medicine in journals such as The Psychoanalytic Quarterly and the Journal of the International Psychoanalytic Association.

Like Franz Alexander, Sandor Rado pushed for medical analysis in the work he did in the New York Psychoanalytic Society as well as the institute he started at Columbia University. Rado, before moving to the United States, worked in the Berlin Psychoanalytic Institute. With the threat of Hitler growing in Europe, Rado had come to the United States like other refugee

\footnotetext{
${ }^{37}$ Alexander, The Medical Value of Psychoanalysis, 188.

${ }^{38}$ Alexander, The Medical Value of Psychoanalysis, 262-263.
} 
analysts. Due to Rado's position as a former member of the Berlin Psychoanalytic Institute as well as his pro medical analysis position, members of the New York Psychoanalytic Society welcomed him into their institute. Rado, who had worked as a member of the International Training Commission was hired by the New York Psychoanalytic Society for the explicit purpose of training new analysts. ${ }^{39}$ Upon arriving in America, Rado began a correspondence with preeminent academic psychiatrist Adolf Meyer. Meyer, who taught psychiatry at Johns Hopkins University, was impressed with Rado's ideas on linking psychoanalysis with organic concepts and reached out to him in friendship. Craig Tomlinson, a historian of psychiatry and psychoanalysis, wrote that much of Rado's theories on sexual behavior borrowed from concepts of Meyerian psychobiology. ${ }^{40}$ Rado, like Alexander, was interested in the biological and physiological aspects of psychoanalysis. He was known by other analysts to be extremely difficult to work with, but nevertheless, he was a prominent figure on the side of medical analysis.

Rado wrote extensively on how psychoanalytic training should be undertaken. He believed that psychoanalytic training method was primarily sound but it also had shortcomings. His primary criticism was that analysts in training were not given intellectual independence. In other words, students were not encouraged to take psychoanalytic concepts and reform them into original material. Rado believed that this lack of independent thought was because of the

${ }^{39}$ Hale, The Rise and Crisis of Psychoanalysis, 34.

${ }^{40}$ Craig Tomlinson, "Sandor Rado and Adolf Meyer: A Nodal Point in the History of Psychiatry and Psychoanalysis," International Journal of Psychoanalysis vol 77 (1996): 970. 
tendency for psychoanalysts to reject new or contradictory ideas. ${ }^{41}$ To solve this problem, Rado promoted a softening of rigid orthodox Freudianism by encouraging students to standby their scientific conclusions in order to allow new concepts to flourish within the psychoanalytic community. In addition, future analysts must be taught to face facts and have a refined sense of scientific judgment because, "Only men who are capable of facing facts fearlessly can be good scientists and good physicians. ${ }^{42}$ In this sense, Rado pushed for a psychoanalysis that would allow future analysts to be able to think freely and explore their own ideas. This statement could possibly be an attack on Freud's overbearing position within the psychoanalytic community. However, when juxtaposing this statement with other material that Rado published, one can assume that Rado promoted the idea of psychoanalysts becoming more integrated with medicine.

Relations between the APsaA and the IPA continued to deteriorate during the mid 1930s. In 1936, while Jones was frantically trying to persuade Americans to remain a part of the IPA, Rado came forward with a radical resolution to solve the problem between the two associations. He claimed that he wrote the resolution on behalf of the New York Psychoanalytic Society. The resolution itself proposed that the International Training Commission needed to dissolve all of its monitoring and standard setting functions and become an informal institution with the sole purpose of exchanging information between European and American institutes. This proposition created alarm not only from the IPA but also from the New York Psychoanalytic Society members. Both sides felt that this would cripple the IPA and dissolve it into a large group of

${ }^{41}$ Sandor Rado, "Scientific Aspects of Training in Psychoanalysis," In The New York Psychoanalytic Institute Report of the Academic Years 1934-1937 (New York: New York Psychoanalytic Institute, 1937), 5

${ }^{42}$ Sandor Rado, "Scientific Aspects of Training in Psychoanalysis," 10-11. 
small autonomous institutes with no overarching leadership. ${ }^{43}$ In fact, New York analysts said that the resolution was entirely Rado's own ideas and that it was not shared by other members of the New York Psychoanalytic Society. Rado's motion was voted upon and unanimously rejected. In that brief moment, both the IPA and the APsaA were united on a similar against Rado's resolution. $^{44}$

Nevertheless, Rado's resolution foreshadowed events at $15^{\text {th }}$ IPA Congress in Paris in 1938. At this conference, the American delegation showed up with a resolution that was similar to the one Rado had unsuccessfully proposed two years prior. During that two year gap, American analysts had dealt with more numerous accounts of quackery, particularly on the West Coast. They felt that the medical image of American psychoanalysis was threatened by lay analysts and drastic measures needed to be taken to resolve this problem. ${ }^{45}$ The American's resolution was essentially a three part ultimatum for the IPA. First, the International Training Commission would be abolished. Second, immigrants who came to the United States would no longer get free floating membership in the IPA. Free floating membership allowed analysts from Europe to come to the United States and still be part of the IPA. The removal of this clause meant that analysts who came to the United States would have to accept American prerequisites to join the IPA and other American societies. The American analysts believed that if enacted, this resolution would disallow lay analysts to operate in the United States. Third, the IPA would meet only for scientific matters and no longer have any administrative control over American policy making. If these policies were not accepted, the Americans were prepared to leave the

\footnotetext{
${ }^{43}$ Wallerstein, Lay Analysis: Life Inside the Controversy, 39.

${ }^{44}$ Wallerstein, Lay Analysis: Life Inside the Controversy, 39-40.

${ }^{45}$ Wallerstein, Lay Analysis: Life Inside the Controversy, 40.
} 
IPA. ${ }^{46}$ Based on this ultimatum, it appeared that the Americans were set upon seceding from the IPA. In a last act of desperation, Jones delayed any vote by setting up a committee to address the concerns presented by the American delegation. Following the committee's presentation of findings, the IPA was supposed to have a vote in $1940 .{ }^{47}$ However, because of the breakout of World War II in Europe, this meeting never occurred. The APsaA took it upon itself to enact the resolution that they had presented in 1938. Thus, lay analysis was effectively crippled in the United States. This action would later be called the "1938 Rule."

Like the arguments presented by lay analysts, those made by medical analysts stemmed from a lack of disciplinary identity in psychoanalysis. Remember, Freud's work originated out of medicine through his work with Charcot. Additionally, Freud agreed that medical knowledge could improve the diagnostic capabilities of psychoanalysis for finding organic causes of mental illness. However, Freud also made it well known that for him, psychoanalysis was much more than a part of the medical field of psychiatry, and that medicine had no business in controlling psychoanalysis. Freud argued that psychoanalysis should not be defined as only a medical discipline. Americans saw things differently in the sense that they felt psychoanalysis would benefit professionally by integration with medicine. The argument made by Franz Alexander in The Medical Value of Psychoanalysis articulates how this integration would benefit both psychoanalysis and medicine in general. Psychoanalysis provided a greater understanding of mental illnesses, such as psychosomatic disorders. This understanding would be beneficial for psychiatrists and doctors in treating patients. It also provided insight into psychobiology which would help doctors to better understand the ways in which the mind worked. In return,

\footnotetext{
${ }^{46}$ Wallerstein, Lay Analysis: Life Inside the Controversy, 44.

${ }^{47}$ Wallerstein, Lay Analysis: Life Inside the Controversy, 45.
} 
psychoanalysts would obtain the legitimacy and professional status that doctors received following the Flexner Report.

The main fear that medical analysts seemed to share was the idea that lay analysis would de-legitimize their status as a profession. When medical analysts Reich or Oberndorf made statements that psychoanalysis received little contribution from non-medical disciplines, they were making a judgmental decision to direct psychoanalysis away from practice in those types of disciplines. Medical analysts saw the disciplinary trajectory of psychoanalysis being threatened by association with lay analysts. If all analysts could abide by the same required training and education, then psychoanalysts as a whole would be unified under the requirement for medical training and not exist as an eclectic assortment of practitioners from different disciplinary backgrounds. However, psychoanalysts never achieved a disciplinary unity following the events of the 1938 Rule. Instead, new problems arose that created further schisms within the psychoanalytic community as analysts further debated the direction of psychoanalytic practice. 


\section{Chapter V: The Psychoanalytic Civil Wars, a Continuation of the Conflict}

After the "1938 Rule."

The ruling at the IPA conference in Paris demoralized lay analysts in America and effectively crushed lay analysis in America except for those refugee lay analysts who had been grandfathered into American psychoanalytic societies. Additionally, with the outbreak of World War II in Europe, the European and American psychoanalytic communities became separated from each other. Consequently, refugee analysts in America had little support from European societies. For the American medical analysts, the 1938 Rule was a victory. Finally, the APsaA had full control over psychoanalytic training requirements and a unified idea of how psychoanalysis should be practiced and taught. The new goal of American psychoanalysis was to present itself as a professional science for the treatment of mental health disorders. However, this vision of a unified professionalized psychoanalysis never occurred because new problems arose which split the American psychoanalytic community apart. These events, deemed the psychoanalytic civil wars by Jones,(a term later borrowed by historians of psychoanalysis), dramatically changed the psychoanalytic communities in the United States. These new conflicts were generational and pitted two new sides against each other. The "orthodox" side consisted of the new generation of American analysts who believed that they were best suited to organize and practice psychoanalysis. While the other group known as the "dissidents," consisted of many of 
the early psychoanalysts from both Europe and America who had practiced psychoanalysis in its infant stages. ${ }^{1}$

The factors shaping the psychoanalytic civil wars were carried over from the conflicts caused by the immigration of refugee analysts to America. During the early thirties, American analysts felt threatened by European refugee analysts because at the time, competition for analytic work was very high. ${ }^{2}$ American analysts, who had learned from European teachers, now saw themselves as the foremost authorities for psychoanalytic matters in the United States. These generational conflicts had an adverse effect upon the relationship between American and European analysts. Many of the younger Americans resented the presence and the actions of older émigré European analysts, who were attempting to create psychoanalytic policy. Members of this new generation included Lawrence Kubie, Ives Hendricks, and Abraham Kardiner. Kubie was an executive in the New York Psychoanalytic Society during the psychoanalytic civil wars and he stated that the problems in American psychoanalysis centered on the presence of different "cliques." ${ }^{3}$ He argued that these cliques generated an environment of mutual distrust and hostility. Kubie felt that he was not a member of any clique even though in the early thirties he had sided with the young American analysts against both European and American analysts from the previous generation. ${ }^{4}$ Historian Kenneth Eisold asserts that there were three different types of cliques within the New York Psychoanalytic Society. The first

${ }^{1}$ Nathan G. Hale, The Rise and Crisis of Psychoanalysis in the United States: Freud and the American 1917-1985, (Oxford: Oxford University Press, 1995), 135.

${ }^{2}$ Hale, Rise and Crisis, 117.

${ }^{3}$ Kenneth, Eisold. "The Splitting of the New York Psychoanalytic Society and the Construction of Psychoanalytic Authority," International Journal of Psychoanalysis 79 (1998): 871.

\footnotetext{
${ }^{4}$ Hale, Rise and Crisis, 118.
} 
clique consisted of analysts whom Eisold labeled as revisionist who reshaped Freud's psychoanalytic theories with their own ideas. An example of a revisionist psychoanalyst was Karen Horney. Horney believed that social and cultural factors played a more important role in neuroses than was previously thought. ${ }^{5}$ The second clique consisted of analysts who spoke out against orthodox psychoanalysis and fostered a relationship with medical psychiatry. The third clique included the new group of young American analysts who advocated for strict training rules. Additionally, there was a sprinkling of older émigré analysts who joined the various cliques. ${ }^{6}$ Eisold claims that these cliques fought over issues involving who had the organizational authority to dictate policy for American psychoanalysis. ${ }^{7}$ This clash for power within the American psychoanalytic community escalated with events such as the death of Freud and the search for an adequate successor to continue Freud's work. In a letter to his long-time friend Smyth Ely Jellife, Karl Menninger wrote that the death of Freud had brought out many analysts who strove for the right to be Freud's replacement. ${ }^{8}$

There are several key events that mark the psychoanalytic civil wars. The first was the departure of Karen Horney and several other analysts from the New York Psychoanalytic Society followed by Horney's formation of the Association for the Advancement of Psychoanalysis and its eventual split off into the William Alanson White Society. Subsequently, another group of analysts from the Association for the Advancement of Psychoanalysis left to

\section{${ }^{5}$ Susan Quinn, A Mind of Her Own: The Life of Karen Horney (New York: Summit} Books, 1987), 314-316.

${ }^{6}$ Eisold, "The Splitting of the New York Psychoanalytic Society," 871-872.

${ }^{7}$ Eisold, "The Splitting of the New York Psychoanalytic Society," 972.

${ }^{8}$ Karl Menninger to Smyth Ely Jeliffe, April 9, 1942. in The Selected Correspondence of Karl Menninger: 1919-1945 (New Haven: Yale University Press, 1988), 364. 
become members of the New York Medical College. The last event was Sandor Rado's establishment of the Columbia Psychoanalytic Clinic at Columbia University. ${ }^{9}$

Horney's controversial status within the psychoanalytic community started in the early twenties. Frequently, Horney challenged Freud about his ideas on women's sexuality. ${ }^{10}$ When she arrived in America, she worked with Franz Alexander at University of Chicago but later moved to teach at the New York Psychoanalytic Society. ${ }^{11}$ Upon her arrival, a conflict immediately arose between herself and Sandor Rado. Rado became angry when he found out that Horney was teaching a class that he had previously taught, and he complained to administration of the New York Psychoanalytic Society to get Horney fired. Additionally, Horney's publication of New Ways in Psychoanalysis stirred up controversy with other members of the New York Psychoanalytic Society who believed that Horney had written her book for a lay psychoanalytic audience. ${ }^{12}$ Horney, who had previously spoken out against lay analysis, was now accused of writing to the lay population. New Ways in Psychoanalysis was an argument for psychoanalysts to consider the cultural and societal environment when diagnosing a patient. ${ }^{13}$ Horney's book provided a contrary view to medical analyst's beliefs that mental illness was tied to medicine and biology. In 1940, Horney was relegated to a teaching position and her status

${ }^{9}$ John Frosch, "The New York Psychoanalytic Civil Wars," Journal of the APsaA 39 (1991): 1039-1040.

${ }^{10}$ Hale, Rise and Crisis, 139-140.

${ }^{11}$ Frosch, " The New York Psychoanalytic Civil Wars,” 1043.

${ }^{12}$ Hale, Rise and Crisis, 138.

${ }^{13}$ Horney, New Ways in Psychoanalysis, 170-179. 
within the New York Psychoanalytic Society was downgraded from instructor to lecturer. ${ }^{14}$ This demotion led Horney to eventually abandon the New York Psychoanalytic Society in 1941. After her resignation she was described as joyfully leading a group of psychoanalysts out of the Society's headquarters to the tune of a hymn. ${ }^{15}$ Horney then went on to found the Association for the Advancement of Psychoanalysis. ${ }^{16}$

Ironically, later the same year, Rado found himself in a similar situation to Horney. His status as educational director, which he had held for ten years, was revoked by the New York Psychoanalytic Society. Since his arrival in the early 1930s, Rado had clashed with orthodox psychoanalysts on many different issues. Robert Waelder, in a letter to Otto Fenichel, wrote that analysts like Rado had taken Freud's ideas and used them against him in what he called a "castrative assault." ${ }^{, 17}$ Brill described Rado as brilliant but also contentious and touchy. ${ }^{18}$ This unpopularity within the New York Psychoanalytic Society eventually led to his departure and his subsequent founding of the Columbia Psychoanalytic Institute with the help of analysts such as David Levy, Abram Kardiner and Phyllis Greenacre. ${ }^{19}$ Levy, Kardiner, and Greenacre were friends of Rado's and agreed with many of his psychoanalytic concepts.

${ }^{14}$ Quinn, A Mind of Her Own, 348.

${ }^{15}$ Eisold, "The Splitting of the New York Psychoanalytic Society," 870.

${ }^{16}$ Frosch, "New York Psychoanalytic Civil Wars," 1048.

${ }^{17}$ Robert Waelder to Otto Fenichel, Aug 13, 1938, Fenichel Papers, in Hale, Rise and Crisis, 136.

${ }^{18}$ A.A Brill to Ernest Jones, Feb. 29, 1936, Ernest Jones Papers, in Hale, Rise and Crisis, 138.

${ }^{19}$ Eisold, "The Splitting of the New York Psychoanalytic Society," 871. 
Another event in 1941 provides a perspective on some of the personal relationships within the New York Psychoanalytic Society. Historians labeled this as the "Zillboorg Affair." Gregory Zillboorg was a prominent figure in the New York Psychoanalytic Society and was also a member of the new generation of American psychoanalysts. In 1941, Franz Alexander received a phone call from a former patient of Zillboorg's. It seemed that Zilboorg had found out about his client's financial status and taken advantage of him. The client told Alexander that Zillboorg had at first just asked for a few favors. However, these favors eventually grew into Zillboorg asking for five thousand dollars in advance to treat the patient's drinking problem. This resulted in the patient contacting Alexander at the suggestion of a friend. Following the incriminating phone call he had received from the patient, Alexander took steps to have Zillboorg banned from psychoanalytic practice. Alexander believed this unethical behavior was detrimental to the image of a professionalized psychoanalysis. However, when Zillboorg learned of Alexander's attempt to have him removed from practice he shot back at Alexander by saying this was personal attack from Alexander to discredit Zillboorg, and Alexander was misusing psychoanalysis. The Ethics Committee of the New York Psychoanalytic Society moved for Zillboorg's removal with the vote of nine to three yet Zillboorg used his influence within the Society to have the charges against him dropped. He remained a member of the New York Psychoanalytic Society with good standing. ${ }^{20}$

Following the 1938 Rule, American psychoanalysis did not obtain the intended unity that analysts believed would occur with the abolition of lay analysis. Instead, it splintered and became even more divided than it had been in previous struggles with the IPA. In the late twenties and thirties, the main conflict within the psychoanalytic community had been whether

\footnotetext{
${ }^{20}$ Frosch, "New York Psychoanalytic Civil Wars," 1051-1052.
} 
lay analysis should be allowed. In the late thirties and forties, the problem involved these generational conflicts. Both conflicts centered on who had the power to dictate policy within the psychoanalytic movement. The struggle for power intensified in the psychoanalytic civil wars with the struggle to find the legitimate successor to carry on Freud's legacy.

Notwithstanding the internal problems within the psychoanalytic community, the American involvement in World War II contributed to an increased prominence for psychoanalysts and psychoanalysis. ${ }^{21}$ While the Depression had made patients scarce for many analysts, World War II had opposite effect. With the growing number of neuropsychiatric disorders showing up as a result of World War II combat, psychoanalysts were inundated with new patients. Psychoanalysis became one of the primary treatment methods for dealing with psychosomatic disorders that arose on the battlefield. ${ }^{22}$ William Menninger, who ran the psychoanalytic clinic in Topeka, Kansas, was appointed to the position of chief psychiatrist to the Army in $1943 .{ }^{23}$ Other psychoanalysts took up additional positions of authority within the military as well. ${ }^{24}$ The actions of psychoanalysts during World War II had two different results. The first was an increased popularity with the general American populace through film and literature. The second was that psychoanalysts were confronted with millions of soldiers coming home from the war requiring treatment for their mental illnesses. ${ }^{25}$

\footnotetext{
${ }^{21}$ Hale, Rise and Crisis, 187.

${ }^{22}$ Hale, Rise and Crisis, 190.

${ }^{23}$ Hale, Rise and Crisis, 190.

${ }^{24}$ Hale, Rise and Crisis, 198.

${ }^{25}$ Hale, Rise and Crisis, 207-209
} 
While the psychoanalytic movement gained prominence as a result of World War II, the discord within the psychoanalytic community had continued. In 1948, Menninger became president of the APsaA and proposed radical changes to psychoanalysis as a whole. In his inauguration speech, Menninger pled with psychoanalysts to forsake their bickering over orthodox versus revisionist and unite together. If analysts were able to join together, the integration with medicine could finally occur. He also made controversial statements such as proposing to abandon the training analysis completely. ${ }^{26}$ The idea to abandon the training analysis was controversial because the training analysis was a standard training procedure that Freud created in the early days of psychoanalysis. However, his suggestion was ultimately rejected by the APsaA. Menninger would no longer consider himself to be a psychoanalyst from that point forward. Instead he referred to himself as a "psychodynamic psychiatrist.",27

Kenneth Eisold argues that while lay analysts in the United States were forced to accept the ban on lay analysis, they reinforced a loyalty to Freud and pushed for a stronger stance of orthodoxy within American psychoanalysis. While they were unable to sway the American stance on lay analysis, they were able to drive out many of the deviants who had rebelled against Freud in the past such as Horney and Rado. ${ }^{28}$ This change in American psychoanalysis finally legitimatized American psychoanalysis to Freud posthumously.

Following the Allied victory in World War II, the IPA came back into contact with the APsaA. For the next several years, both the IPA and the APsaAs discussed the ramifications of the 1938 Rule. In 1948, Earnest Jones, who was still president of the IPA, reached out to the

\footnotetext{
${ }^{26}$ Rebecca Jo Plant, "William Menninger and American Psychoanalysis, 1946-1948," History of Psychiatry 16 (2005): 182.

${ }^{27}$ Plant, “Menninger," 196.

${ }^{28}$ Eisold, "The Splitting of the New York Psychoanalytic Society," 879.
} 
APsaA to discuss how the relationship between the two organizations would continue. ${ }^{29} \mathrm{~A}$ conference was scheduled in 1949 for Zurich, in which the actions taken in 1938 would be discussed in an attempt to find a compromise between the two associations. Adam Limentani, an archivist of the IPA, wrote that the tensions between the IPA and APsaA had decreased and that both sides made compromises. ${ }^{30}$ There were several important outcomes from this rekindled conversation between the two associations. First, the International Training Commission was not restarted and therefore the Americans were able to keep and maintain their own training programs. Americans also kept their autonomy and had control over any future psychoanalytic institutes in the United States. In return, the APsaA would support direct membership to nonmedical professionals who wished to apply for membership in the IPA. However, nonmedical analysts remained unable to join most American societies. ${ }^{31}$ A final pledge of unity was the alternation of IPA presidency in the years to come between European and American members.

Refugee analysts had to accept the fact that lay analysis was not allowed in the United States following the 1938 Rule. However, that did not stop some lay analysts from continuing to practice psychoanalysis. Theodore Reik continued to practice in the United States following his rejection from the New York Psychoanalytic Society. In the early 1940s, Reik taught students from non-medical backgrounds at the newly formed William Alanson White Psychoanalytic

${ }^{29}$ Robert Wallerstein, Lay Analysis: Life Inside the Controversy (Hillsdale: The Analytic Press, 1998), 52.

${ }^{30}$ Adam Limentani, "A Brief History of the IPA," The International Journal of Psychoanalysis 77 (1996): 156.

${ }^{31}$ Wallerstein, Lay Analysis: Life Inside the Controversy, 55. 
Institute. ${ }^{32}$ In the following years, Reik informed many of his colleagues that he planned on becoming the best known psychoanalyst in the United States. ${ }^{33}$ In 1948 he published one of his most famous psychoanalytic publications, The Third Ear. This book provided an account of his psychoanalytic works framed in such a way that the general public could read it. It became one of the most influential books for the cause of lay analysis. ${ }^{34}$ In 1948, Reik founded the National Psychological Association for Psychoanalysis which was an organization devoted to assisting lay analysts in the United States. ${ }^{35}$ Then, in 1952, the NPAP started publishing a journal called Psychoanalysis which later merged with The Psychoanalytic Review in $1958{ }^{36}$ Theodore Reik was the editor in chief and the purpose of this particular journal was to provide a place where lay analytic ideas could be published. In the first issue of Psychoanalysis, Reik published three letters that he received from Freud in 1938. In these letters, Reik asked Freud what was the best way for psychoanalysis to be continued in practice and theory. Freud responded by reaffirming his belief that psychoanalysis should not become "a handmaiden of psychiatry" and that it should rely more upon the social sciences in the future. ${ }^{37}$

One can suspect that the psychoanalytic civil wars and the foundation of the NPAP resulted from the struggle between psychoanalysts to establish a legitimate successor to Freud

${ }^{32}$ Murray H. Sherman, "Theodore Reik and Lay Analysis," The Psychoanalytic Review 75 (1988): 386.

${ }^{33}$ Sherman, "Theodore Reik and Lay Analysis," 387.

${ }^{34}$ Sherman, "Theodore Reik and Lay Analysis," 388.

35 “About NPAP,” accessed on March 13 $3^{\text {th }}, 2012$. http://www.npap.org/about/index.html.

${ }^{36}$ Leila Lerner, "The Psychoanalytic Review and Lay Analysis," The Psychoanalytic Review 75 (1988): 356-357.

${ }^{37}$ Lerner, "The Psychoanalytic Review" 357. 
following his death in 1939. In this sense, it is intriguing that the American psychoanalysts basically disregarded Freud's ideas on lay analysis while attempting to show that they were the successors to Freud's legacy. Reik, however, believed that it was his duty to continue Freud's legacy and promote the work done by lay analysts. It would seem that for most psychoanalysts, lay and medical, it was important to attach themselves to the idea of orthodox Freudianism in order to become legitimate successors to Freud. The struggle for approval from Freud by both lay and medical analysts continued even after Freud's death.

Perhaps, the argument surrounding lay analysis and medical is just part of a larger problem within the psychoanalytic community namely the struggle by psychoanalysts to decide what psychoanalysis was best used for. The events of the psychoanalytic civil wars give credence to that proposition. Eisold, in an article focusing on conflicts and schisms in psychoanalytic institutes, argued that the nature of psychoanalytic work put psychoanalysts under an extreme amount of emotional stress. This emotional stress came from the analyst's own use of emotions, like empathy, to try to really understand what patients were going through. ${ }^{38}$ This stress increased anxiety for psychoanalysts. To address this anxiety, analysts had to consult psychoanalytic theory that had been taught to them by their training analyst. ${ }^{39}$ Analysts learned most of their techniques not through books but through the training analysis that every psychoanalyst had to participate in. Thus, analysts developed a preference for a particular method that they learned from their training analyst and this led to several different

${ }^{38}$ Kenneth Eisold, "The Intolerance of Diversity in Psychoanalytic Insititutes," The International Journal of Psychoanalysis 75 (1995): 787.

${ }^{39}$ Eisold, "The Intolerance of Diversity," 789. 
and sometimes conflicting schools of psychoanalysis. ${ }^{40}$ Perhaps it is for this reason that Menninger proposed to completely remove the training analysis from psychoanalytic curriculum. In his address as president of the APsaA, he called for a unity between psychoanalysts to forsake their differences and join together with medical disciplines. It is possible that Menninger saw the training analysis as an obstacle to unification. However, following the argument made by Eisold, this radical suggestion would have been seen as an attack upon Freud himself and therefore rejected. Eisold's argument provides another example for the conflicting disciplinary identity for psychoanalysis. He explains how the different schools of psychoanalytic contributed to the creation of schisms within psychoanalytic institutes. In my examination of the conflict of lay and medical analysis, I have made the argument that this particular conflict stemmed from conflicting ideas for the disciplinary identity of psychoanalysis. The various psychoanalytic schools of thought contributed to that lack of disciplinary identity by their nature. The personal relationship between training analyst and learning analyst intensified the various psychoanalytic conflicts that took place. In the end, the conflict of lay and medical analysis allows historians of psychoanalysis to take a closer look past psychoanalytic theory and examine the structure, or lack of structure, of one of the most dynamic techniques for understanding mental health.

\footnotetext{
${ }^{40}$ Eisold, "The Intolerance of Diveristy," 790.
} 


\section{Work Cited}

Alexander, Franz. "Discussion: Lay Analysis." The International Journal of Psychoanalysis 8 (1927): 224-230.

Alexander, Franz. The Medical Value of Psychoanalysis. New York: W.W. Norton, 1936.

Brill, A.A. "Discussion: Lay Analysis." The International Journal of Psychoanalysis 8 (1927): 220-222.

Carnegie Foundation. About Carnegie" accessed on May $3^{\text {rd }}, 2012$. http://www.carnegiefoundation.org/about-us/about-carnegie.

Castellani, Brian and Frederic W. Hafferty. "The Increasing Complexities of Professionalism." Academice Medicine 85 (2010) 288-301.

Eisold, Kenneth. "The Splitting of the New York Psychoanalytic Society and the Construction of Psychoanalytic Authority." International Journal of Psychoanalysis 79 (1998): 871-885.

Eisold, Kenneth. "The intolerance of diversity in psychoanalytic institutes." The International Journal of psycho-analysis 75 (1994): 785-800.

Eissler Kurt, Medical Orthodoxy and the Future of Psychoanalysis. New York: International Universities Press, 1965.

Flexner, Abraham. "Is Social Work a Profession?” Research on Social Work Practice 11 (2001): 152-165.

Flexner, Abraham. Medical Education in the United States and Canada, (New York: Arno Press, 1910).

Duffy, Thomas P. "The Flexner Report: 100 Years Later." Yale Journal of Biology and Medicine 77 (2011): 269-276.

Forrester, John. "A Whole Climate of Opinion: Rewriting the History of Psychoanalysis." in Discovering the History of Psychiatry, (New York: Oxford University Press, 1994) 174190.

Freud, Sigmund. "Concluding Remarks on the Question of Lay Analysis," International Journal of Psychoanalysis 8 (1927): 392-401.

Freud, Sigmund. On the History of the Psychoanalytic Movement (New York: W.W. Norton \& Company, 1914). 
Freud, Sigmund. The Question of Lay Analysis. New York: W.W Norton \& Company, 1927.

Freud, Sigmund. Wild Psychoanalysis. Translated by Alan Bance. London: Penguin Books, 2002.

Frosch, J. "The New York Psychoanalytic Civil War." Journal of the American Psychoanalytic Association 39, no. 4 (1991): 1037-1064.

Gay, Peter. Freud: A Life for Our Time. New York: W.W Norton \& Company, 1988.

Hale, Nathan G. Freud and the Americans: The beginnings of Psychoanalysis in the United States 1876-1917 (New York: Oxford University Press, 1971).

Hale, Nathan G. The Rise and Crisis of Psychoanalysis in the United States: Freud and the Americans 1917-1985 (New York: Oxford University Press, 1995).

Horney, Karen. New Ways in Psychoanalysis. New York: W.W Norton \& Company, 1939.

Horney, Karen. "Discussion: Lay Analysis." The International Journal of Psychoanalysis 8 (1927): 255-258.

Jones, Ernest. The Life of Sigmund Freud. New York: Basic Books Inc., 1961.

Jones, Ernest. "Discussion: Lay Analysis" The International Journal of Psychoanalysis 8 (1927): 174-197.

Kubie, Lawrence. Practical \& Theoretical Aspects of Psychoanalysis. New York: International Universities Press, 1950.

Kurzweil, Edith. The Freudians (New Haven: Yale University Press, 1989).

Limentani, Adam. "A Brief History of the International Psychoanalytic Association." The International Journal of Psychoanalysis 77 (1996): 149-158.

Lerner, Leila, "The Psychoanalytic Review and Lay Analysis." The Psychoanalytic Review 75 (1988): 356-360.

Ludmerer, Kenneth M. "Commentary: Understanding the Flexner Report," Academic Medicine 85 (2010): 193-196.

Lunbeck, Elizabeth. The Psychiatric Persuasion: Knowledge, Gender, and Power in Modern America, (Princeton: Princeton University Press, 1994).

Menaker, E. "Early struggles in lay psychoanalysis: New York in the thirties, forties, and fifties." 
Psychoanalytic review 75, no. 3 (1988): 373-379.

Menninger, Karl. The Selected correspondence of Karl A. Menninger, 1919-1945. Edited by Howard J. Faulkner and Virginia D. Pruitt. New Haven: Yale University Press, 1988.

Micale, Mark S. and Roy Porter. "Reflections on Psychiatry and its Histories." in Discovering the History of Psychiatry (New York: Oxford University Press, 1994) 3-36.

Mora, George. "Early American Historians of Psychiatry." in Discovering the History of Psychiatry, (New York: Oxford University Press, 1994) 53-80

National Psychological Association for Psychoanalysis. "About NPAP," accessed on March $13^{\text {th }}$ , 2012. http://www.npap.org/about/index.html.

Nunberg, Herman. Minutes of the Vienna Psychoanalytic Society, Vol.1 1906-1908 (New York: International University Press, 1962).

Oberndorf, C.P. "Discussion: Lay Analysis." The International Journal of Psychoanalysis 8 (1927): 210-206.

Quinn, Susan. A Mind of Her Own: The Life of Karen Horney (New York: Summit Books, 1987).

Rado, Sandor. "Scientific Aspects of Training in Psychoanalysis." In The New York Psychoanalytic Institute Report of the Academic Years 1934-1937. New York: New York Psychoanalytic Institute, 1937.

Reich, Wilhelm. "Discussion: Lay Analysis." The International Journal of Psychoanalysis 8 (1927): 250-254.

Reik, Theodore. "Discussion: Lay Analysis." The International Journal of Psychoanalysis 8 (1927): 240-243.

Reik, Theodore, "The Therapy of the Neuroses and Religion." International Journal of Psychoanalysis 10 (1929): 292-302.

Roheim, Geza. "Discussion: Lay Analysis." The International Journal of Psychoanalysis 8 (1927): 244-245

Plant, Rebecca. "William Menninger and American psychoanalysis, 1946-48." History of Psychiatry 16, no. 2 (June 1, 2005): 181-202.

Sherman, Murray H. “Theodor Reik and Lay Analysis," Psychoanalytic Review 75 (1988): 38092.

Schudson, Michael. "The Flexner Report and the Reed Report: Notes on the History of 
Professional Education in the United States." Social Science Quarterly 55 (1974): 347361.

Sullivan, William M. “Commentary: Expanding Flexner's Through New Understanding." Academic Medicine 85 (2010): 201-202.

Thompson, Clara. "The Different Schools of Psychoanalysis." The American Journal of Nursing 57 (1957): 1304-1307.

Tomlinson, Craig. "Sandor Rado and Adolf Meyer: A nodal point in American psychiatry and psychoanalysis." The International journal of psycho-analysis. 77, no. 5 (1996): 963-982.

Vatz, Richard E. and Lee S. Weinberg. "The Rhetorical Paragigm in Psychiatry History: Thomas Szasz and the Myth of Mental Illness." in Discovering the History of Psychiatry, (New York: Oxford University Press, 1994) 311-330.

Wallerstein, Robert. The Question of Lay Analysis, (Hillsdale: The Analytic Press, 1998).

Young-Bruehl, "A History of Freud Biographies." in Discovering the History of Psychiatry (New York: Oxford University Press, 1994) 156-174. 